analysis of seals, use of herbicides on vegetation between high- and low-water mark, mountain rescue, recording of vegetation changes on grassland, fixation of shifting sand dunes, and interception and arrest of deer poachers operating after midnight. The booklet (obtainable from the Nature Conservancy, 19 Belgrave Square, London, S.W.1, post paid $1 s$. 6d.) contains details of the public relations and educational work carried out by the Conservancy and is itself a model of how such publications should be produced.

\section{Protection of the Shropshire Hills}

THE Minister of Housing and Local Government, Mr. Henry Brooke, has confirmed an order made by the National Parks Commission, establishing about 300 square miles in Shropshire as an area of outstanding natural beauty. The designated area includes the fine landscape around Church Stretton, with Caer Caradoc, the Long Mynd, the Stiperstones and the long ridge of Wenlock Edge, from which it extends north-east to take in the Wrekin and the Ercall. 'To the south-east, parts of the Clee Hills are included, and to the south-west the Clun Forest area on the Welsh border. Responsibility for preserving and enhancing the natural beauty of the landscape rests with the local planning authority, Salop County Council. Government grants can be made at the rate of 75 per cent toward the cost of treating derelict land, tree planting and preservation work. Grants are also available toward expenditure incurred in making agreements or orders for public access to open country and in appointing wardens. Designation does not of itself provide any additional right of access to private land.

\section{Chinese Scientific Literature}

The Lending Library Unit of the Department of Scientific and Industrial Research has started to collect Chinese scientific literature, and now receives regularly about 150 Chinese scientific and technical periodicals. The Lending Library Unit in London, which forms the nucleus of the new National Lending Library for Science and Technology, which will be set up at Thorp Arch, near Boston Spa, Yorks, in 1961, already has a large collection of Russian scientific literature, which is available to research, industrial and other organizations, through a loans service, and operates a scheme for the translation of Russian scientific literature, in collaboration with the U.S. National Science Foundation. This may possibly be extended in the future to include scientific literature from China.

\section{Bulk Production of Silicon in Britain}

Imperial Chemical Industries, Ltw., has brought into operation a large-scale development plant for the manufacture of high-quality silicon of semiconductor grade. This remarkable material, which costs more than $£ 100$ per pound, has become of commercial importance during the past few years in the manufacture of semi-conductor devices, such as transistors, which are fast replacing conventional thermionic valves in many applications. The I.C.I. plant is operated by its General Chemicals Division on Merseyside. By the middle of this year capacity will approach 4,000 lb. per annum. Plans for much larger production are well advanced. Lump silicon, $p$-type, of resistivity greater than $200 \mathrm{ohm} \mathrm{cm}$. is now available in quantity. Silicon in rod form, deposited direct from vapour and of exceptionally low boron content, is being produced in limited quantities in lengths of $24 \mathrm{in}$. and diameters up to 1 in. These rods are suitable for zone refining.

\section{Smoking Habits}

IT often happens that investigators, particularly in the social sciences, must try to collect the information which they need by using questionnaires. One of the many problems that are apt to arise concerns the reliability of answers to questions which require an exercise of detailed and specific memory. Recently, the Tobacco Manufacturers Standing Committee issued a Research Paper (No. 2) entitled "The Reliability of Statements about Smoking Habits", by G. F. Todd and J. T. Laws (pp. 50 ; 1958). 'This should be consulted by anybody who has to try by questions to obtain factual information about habits or events covering any period in the past from a month or two to several years.

The authors show how statements about current smoking habits are generally reconstructed from a sort of 'mental picture' that the informant has of himself 'in his role as a smoker'. Changes in smoking habits are far more frequent than is generally thought to be the case, and so any information about them which refers to the past, based, as it must be, upon a general and personal assessment of current practices, is very likely to be in error. But the changes do not appear to be distributed in a random manner and, provided the sample groups investigated are large enough and the questions asked are answered seriously, so far as group tobacco consumption is concerned, information gained in this way is probably reasonably accurate in a statistical sense. For individuals, recall is frequently mistaken both as regards the amount and the kind of smoking carried on. Apart from the special topical interest of this study, it has wide methodological implications which ought to be considered by all users of questionnaires.

\section{Bibliographies on Geology}

Within recent years the United States Geological Survey has been very active in the publication of annotated bibliographies ranging over a wide spread of geological topies, many of them of world-wide interest. Among these works is a series of "Contributions to the Bibliography of Mineral Resources" (Bulletin United States Geological Survey, 1019A-L; 1954-58), which embrace separately published chapters reviewing the literature on the iron-ore resources of the world, on the world's quicksilver, titanium and nickel ores, and on the domestic distribution of magnesium salts, thorium and rare-earth deposits, salt beds, asbestos, and various industrial rocks. A second series of "Selected Bibliographies of Uranium Geology" (Bulletin, $1059 A-E ; \quad 1957-58)$ reviews the principal papers on uraniferous coal deposits, phosphorites, hydrocarbons, and uranium-bearing sandstones and igneous rocks in North America. Similar reviews of the international literature (including Russian works) on geophysics are published quarterly under the title "Geophysical Abstracts" (Bulletin, 1048, 1956; 1066, 1957; 1084, 1958); and another noteworthy compilation in the same category is "Bibliography of North American Goology", published yearly. A recently published bibliographical index to North American geology for the decado 1940-49 extends to 2,200 pages (Bulletin, 1049,1957 ).

Apart from Mineralogical Abstracts (shortly to be published in a new format), British activity in geo- 